UDC 504.75

DOI: $10.21668 /$ health.risk/2020.2.02.eng

\title{
SELECTED HEALTH PARAMETERS OF PEOPLE LIVING IN CITIES INCLUDED INTO «CLEAN AIR» FEDERAL PROJECT
}

\author{
B.A. Revich ${ }^{1}$, T.L. Kharkova ${ }^{1,2}$, E.A. Kvasha ${ }^{2}$ \\ ${ }^{1}$ Institute of Economic Forecasting of the Russian Academy of Sciences, 47 Nakhimovskii Ave., Moscow, 117418, \\ Russian Federation \\ ${ }^{2}$ Institute of Demography of National Research University Higher School of Economics, 3 Bolshoi \\ Trekhsvyatitel'skii lane, Moscow, 109028, Russian Federation
}

\begin{abstract}
Our research goal was to assess expected efficiency of «Clean air» Federal project with its activities aimed at reducing ambient air contamination and population health risks.

We revealed that finding solutions to the project tasks on emissions reduction that had been set without taking into account peculiarities of city design, development, landscapes, meteorological conditions, and other factors, would not result in improved ambient air quality. Road and transport systems are to be modernized basing on transport flows modeling and application of calculations taking into account transport flows structure, speed, and intensity as well as some other parameters. Analysis of standardized death rate (SDR) in 2000-2018 revealed the highest total mortality in Chita against a reference city, Lipetsk; mortality due to respiratory diseases was higher in Bratsk, Krasnoyarsk, Magnitogorsk, Nizhniy Tagil, Novokuznetsk, Omsk, Chelyabinsk, Cherepovets, and Chita. Mortality caused by these diseases has been going down since 2007; starting from 2013, the highest mortality due to respiratory diseases has been registered in Krasnoyarsk. Long-term annual average SDR due to neoplasms is rather chaotic in most cities but it is persistently higher than in Lipetsk, the reference city; asymptomatic parameter $(p<0.001)$ indicates discrepancies are valid. In some years, the highest SDR due to lung cancer among men was detected in cities with aluminum productions, such as Krasnoyarsk, Bratsk, Novokuznetsk, as well as in Chita. To assess efficiency of environmental policy aimed at improving ambient air quality in cities, it is necessary to perform epidemiologic activities, including assessment of asthma-like symptoms and bronchial asthma prevalence among children using an international standardized questionnaire and analysis of neoplasms frequency among various population groups.

Key words: ambient air, emissions, "Clean air» Federal project, monitoring, population health, health risk assessment, mortality, bronchial asthma, malignant neoplasms, environmental policy.
\end{abstract}

In 2018, the Russian Federation Government approved National Project «Ecology», which includes the Federal Project «Clean air», aimed at improving the environmental situation and reducing by $20 \%$ the total emission of all pollutants into the air in 12 cities: Bratsk, Krasnoyarsk, Lipetsk, Magnitogorsk, Mednogorsk, Novosibirsk, N. Tagil, Novokuznetsk, Norilsk, Omsk, Chelyabinsk, Cherepovets and Chita by 2024; reducing the number of cities with high and very high levels of air pollution, assessed by the pollution index; at creating an effective air quality monitoring and control system, as well as, which is very important, to track the level of satisfaction of the population with the quality of atmospheric air through sociological surveys. The project developers chose these cities from a formal rather than a substantive position, i.e. based only on the pollutant emissions mass without taking into account their dispersion in the air and public health. The announced project's goal of reducing the total pollutant emissions by 20 percent by 2024 seems to be highly urgent, but the main question arises: can such a factor as reducing emissions really improve air

(c) Revich B.A., Kharkova T.L., Kvasha E.A., 2020

Boris A. Revich - Doctor of Medical Sciences, Professor, Head of Laboratory for Environment Quality Prediction and Population Health (e-mail: brevich@yandex.ru; tel.: +7 (499) 129-36-33; ORCID: https://orcid.org/0000-0002-7528-6643).

Tatiana L. Kharkova - Candidate of Economic Sciences, Senior researcher at Laboratory for Environment Quality Prediction and Population Health; Senior researcher Institute of Demography of National Research University Higher School of Economics (e-mail: tatkharkova@mail.ru; tel.: +7 (910) 479-69-84; OPCID: https://orcid.org/0000-0001-7460-1966).

Ekaterina A. Kvasha - Candidate of Economic Sciences, Senior researcher Institute of Demography of National Research University Higher School of Economics (e-mail: keapost@mail.ru; tel.: +7 (916) 811-19-52; ORCID: https://orcid.org /0000-0002-2003-5484). 
quality, as well as what models this has been proven on, and what positive impact it will have on the health of citizens. The 12 selected cities vary considerably in terms of natural conditions, frequency and severity of adverse weather conditions, planned concepts, type of buildings and urban density, chemical composition of emissions, height of pipes and many other factors that determine the level of air pollution. In previous years, sizable environmental protection actions were taken in Krasnoyarsk, Norilsk and other cities from the above list, but the pollution level is still high, which causes additional health risks. Our critical assessment of a number of provisions of the project [1] coincided partially with the report of the Russian Federation Accounts Chamber ${ }^{1}$, stating the unlikelihood of radical reduction in air pollution. Our work confirms this ultimate conclusion.

Data and methods. Based on Rosstat data, we calculated the age-specific and standardized death rates (SDR) for the main causes of death, which can be attributed to environmentally dependent diseases. For two cities of the «Clean air» project - Norilsk and Mednogorsk, which are included in the list of cities with the air pollution highest level, Rosstat does not have long series of data by different causes of death so these cities were excluded from the analysis. To eliminate the influence of differences in the population age composition, a comparative regional analysis of mortality due to causes of death was conducted on the basis of the calculation standardized death rate, according to ICD-10. The European Standard of 1976, widely used by WHO and Rosstat, was taken as reference. The comparison of these indicators was carried out in relation to $\mathrm{Li}$ petsk - the city with the lowest level of pollution in this group of cities and the absence of significant health risks of the population from emissions from industrial enterprises of the city $[2,3]$.
Linear regression analysis was used to estimate the mortality dynamics (trends). The generally accepted level of $p=0.05$ was taken as a threshold value when deciding on statistically significant difference between trends. Statistical evaluation of SMR differences for 9 cities was determined in relation to the city of comparison - Lipetsk. Chita was excluded from this analysis because of extremely high variation in SMR values. The estimation of SMR differences between the cities was obtained by comparing their median in relation to Lipetsk using the asymptotic significance «p». The hypothesis of inequality was confirmed for most of the indicators, except for all the causes, as well as for cardiovascular diseases (CVD) in men.

Brief description of atmospheric air quality in cities of the Federal Project.

The state control over the air pollution in residential areas is exercised by RosHydroMet (Russian Federal Service for Hydrometeorology and Environmental Monitoring), its territorial subdivisions at stationary observation units, local sanitary and epidemiological supervision bodies, small laboratories of RosPrirodNadzor (Russian Federal Service for Surveillance over Nature Resources), systems for environmental monitoring of Moscow, St. Petersburg, Krasnoyarsk local administrations, and a number of other cities. Unfortunately, the activities of these units are not coordinated due to different estimation methods with different equipment being applied in the process, so it is difficult to obtain reliable data on the pollution level for such a variable environment such as atmospheric air. Based on the data of pollutants in the air, RosHydroMet annually publishes a list of cities with the highest levels of pollution. This list may be changed without explaining the reasons, which may be due not only to the actual improvement in air quality, but also to the peculiarities of the location of stationary posts of the Roshydromet network, the use of archaic equipment, technical malfunctions and others.

\footnotetext{
${ }^{1}$ Report on the results of the expert and analytical event «Monitoring the progress of the national project «Ecology», including expedience of their financial support, achieving goals and objectives, benchmarks, as well as management quality». Accounts Chamber of the Russian Federation, 2020, 41 p. (in Russian).
} 
The studies cities, given the dominance of the type of industry or fuel used, can be divided into several groups, although most cities have different sources of industrial and energy emissions: non-ferrous metallurgy in Bratsk, Mednogorsk and Norilsk; ferrous metallurgy in Cherepovets, Magnitogorsk, Novokuznetsk, N. Tagil, Chelyabinsk and Lipetsk; large pollution sources of various industries using coal - Krasnoyarsk, Omsk. The particularly unfavorable landscape conditions, which prevent pollutants dispersion in the air, are typical for Chita due to power plants operating on lignite coal. Only three cities of the Federal Project are located in the European part of Russia, the rest are in Siberia, where climate conditions are much more unfavorable, and where coal is mainly used as fuel. In Chita, for example, this fuel accounts for $95 \%$ in the combustibles balance. Depending on air pollution level in the last 5 years (2014-2018), the cities may be divided into several categories: with a constantly high pollution level: Bratsk, Krasnoyarsk, Norilsk and Chita; with a high level of pollution in some years: Magnitogorsk, Novokuznetsk, Chelyabinsk; with least high pollution level in these years: Lipetsk, Mednogorsk, N. Tagil, Omsk, Cherepovets. As a rule, in all these cities the increased level of air pollution with the most common substances, such as suspended particles (fine dust), sulfur dioxides and nitrogen, carcinogenic benzene (pyrene) was registered for many years. Cities which have metallurgical industry are also characterized by the presence of a wide range of toxic metals in the air: zinc, lead, copper; provided smelting aluminum in Bratsk, Krasnoyarsk, Novokuznetsk, fluorine hydride is observed. Among these cities, the most unfavorable environmental situation is in Krasnoyarsk, where such major emission sources as aluminum smelter (JSC «RUSAL Krasnoyarsk»), non-ferrous metals plant, cement plant, machine-building plants, tire plant, thermal power plant and many other enterprises are located. In this city, the population health risk from exposure to a complex of carcinogenic substances in the air (hexavalent chromium, benzene, formaldehyde, benz(a)pyrene) resulted in 12 cases of malignant neoplasms per year [4]. Our calculation, carried out in collaboration with Prof. Avaliani S.L., showed that the proportion of additional deaths only from exposure to RM10 reaches $9.3-21.9 \%$ per year from all causes except for the external ones.

The urban population health status in the cities of the «Clean air» project can be assessed based on the most accurate and verified indicator such as mortality. This indicator can be used to assess the impact of polluted air on health along with the assessment of the prevalence of bronchial asthma, congenital malformations among children; analytical epidemiological studies of cancer, etc.

Dynamics of urban mortality in 2000 2018. In all Federal Project cities, there was a gradual decrease in mortality, the rate of which varied depending on the level of mortality in the early 2000s. Figures 1-3 show the differences between cities, in terms of both the level and dynamics of SDR, the similar trend in total mortality, and the differences from the city of Chita, where a much higher mortality rate was registered over the 11 years (2000-2010). However, a relatively significant decrease in mortality in Chita in 2011 compared to 2010 and previous years may be the result of an incorrect correlation between the collected data on the number of deaths and the population estimates used in calculating mortality rates. Thus, in 2011, due to administrative reforms, the population of this city increased by $5.2 \%$. Besides, such a difficult situation in Chita is, of course, related not only to the high level of air pollution, but also to the socio-economic situation. According to the indices of sustainable development, the Chita Region, which became the Transbaikal Territory in 2008 due to its merger with Aginskiy Buryat Autonomous District, was in the lower quartile of this indicator.

The second group in terms of increased total mortality compared to the «conditional control» Lipetsk are cities with aluminum industry enterprises - Bratsk, Novokuznetsk, Krasnoyarsk.

Then follows the group of cities with ferrous metallurgy enterprises: N. Tagil, Magni- 
togorsk, Cherepovets, and also cities with the minimum level: Lipetsk and Omsk.

Mortality by selected causes of death. Using the indicator of asymptotic significance «p» for 12 causes of death separately for the male and female population allowed to identify eight groups of causes for which all cities, except Chita, reliably significantly differed from the corresponding data for Lipetsk.

For Chita, due to significant fluctuations in SDR from selected causes of death, the calculation of this indicator was not carried out. Reliable differences did not appear only in the 3 groups of death causes - all causes (men and women) and cardiovascular diseases (CVD) among women. The reason for the absence of differences in the group «all causes» is due to the presence of external causes of death, the share of which traditionally ranks third in the structure of mortality of men, and fourth to fifth - in the mortality structure of women. At the same time, among the external causes for men and women, injury with unknown intent, suicides and homicides are leading, accounting for $40-60 \%$ of all external causes. The share of transport accidents is also quite significant, and it is higher among women than among men (10-20 and $7-12 \%$ of all external causes, respectively).

Respiratory diseases (RD) and, to a lesser extent, malignant neoplasms may be associated with the negative impact of air pollution. This is shown by many epidemiological studies of Russian and foreign authors based on both meta-analysis of a large array of data from hundreds of cities and clinical and
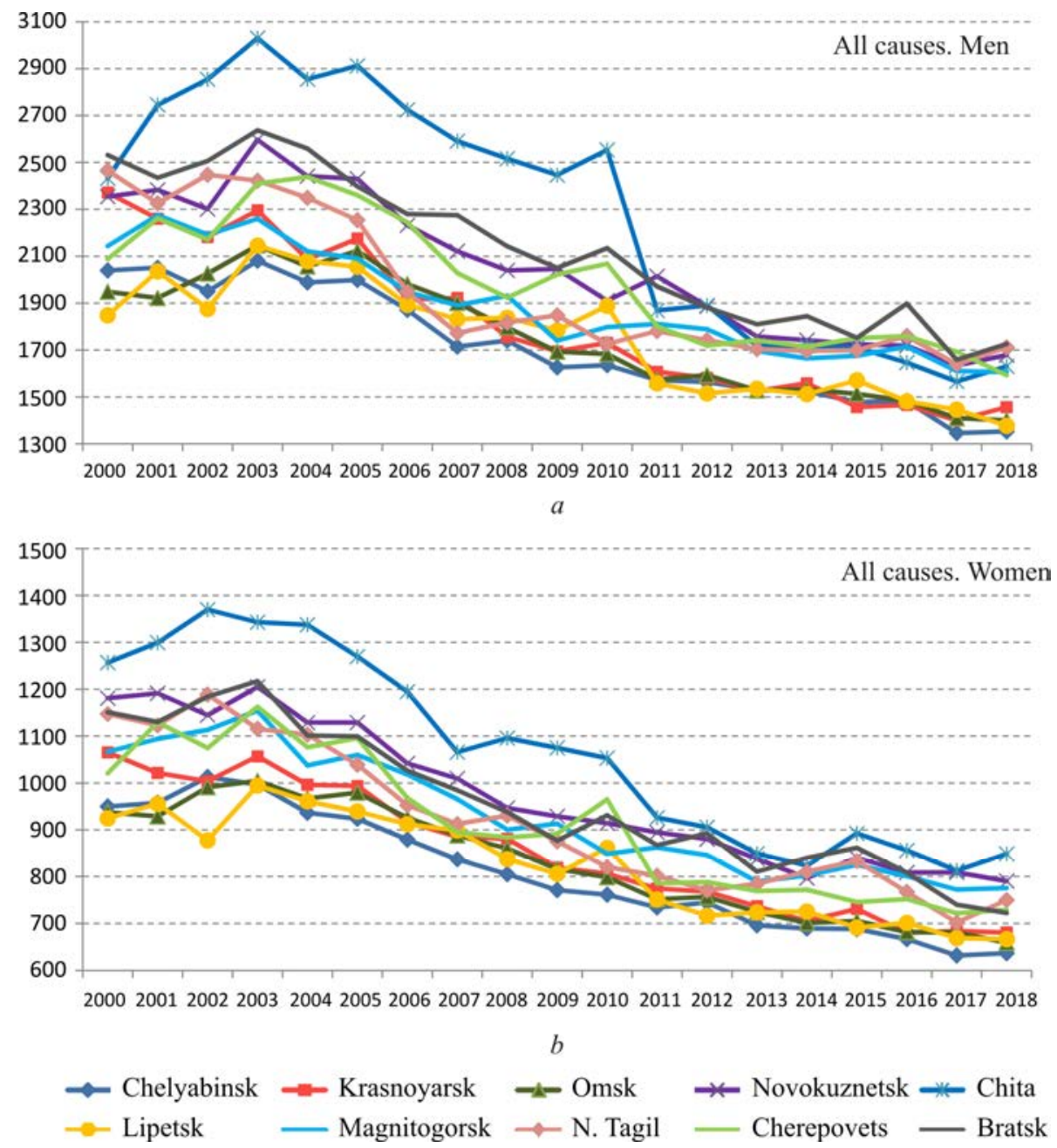

Figure 1. Standardized death rates from all causes in cities with different levels of air pollution, 2000-2018, per 100,000 of population ( $a$ - men, $b$ - women) 
epidemiological studies in the most ecologically problematic cities. SDR of RD in cities with different levels of atmospheric air pollution are varying more significantly than the total mortality. They are the highest among the Chita population and the lowest - in Lipetsk and Omsk. In the period since 2007 mortality from $\mathrm{RD}$ has started to decrease more intensively than in previous years, the fluctuations of the average annual values for the last 5 years (2014-2018) are in a very large range - from 50 to 100 cases per 100,000 (Figure 2). Mortality of both male and female population due to RD in Krasnoyarsk is constantly above the upper boundary of this interval since 2013. In this city, as in Chelyabinsk and Magnitogorsk, high risks of respiratory diseases are revealed due to air pollution $^{2}$ [5]. Whether it is connected with deterioration of the atmospheric air quality in Krasnoyarsk and the regular phenomena of «black sky» is not yet established. The possible reason for this phenomenon - the accumulated long-term influence of the polluting substances the negative effect of which is already manifested in childhood.

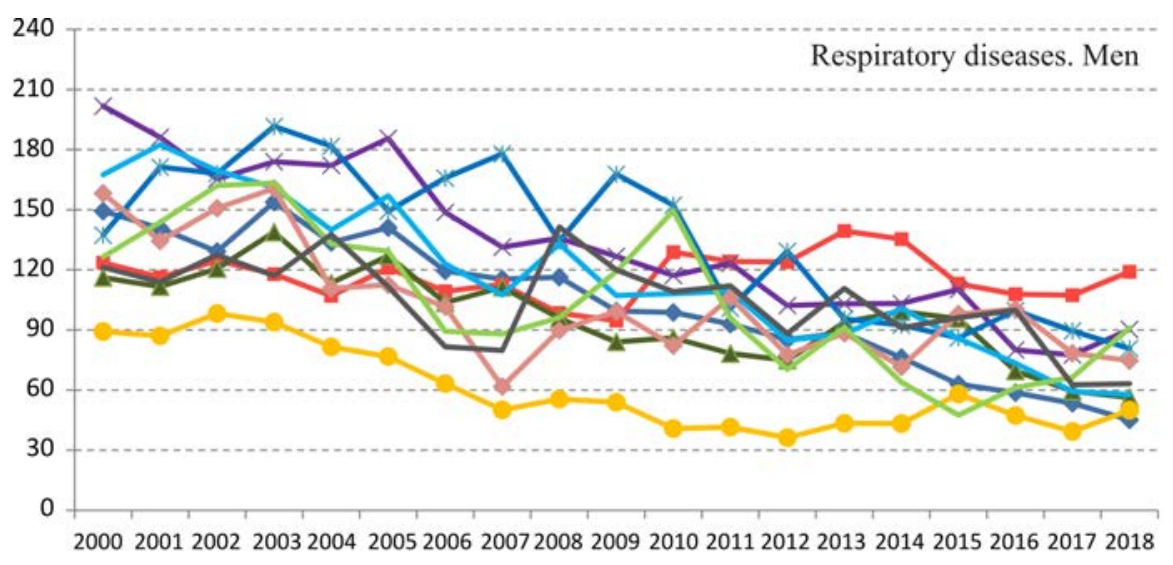

$a$

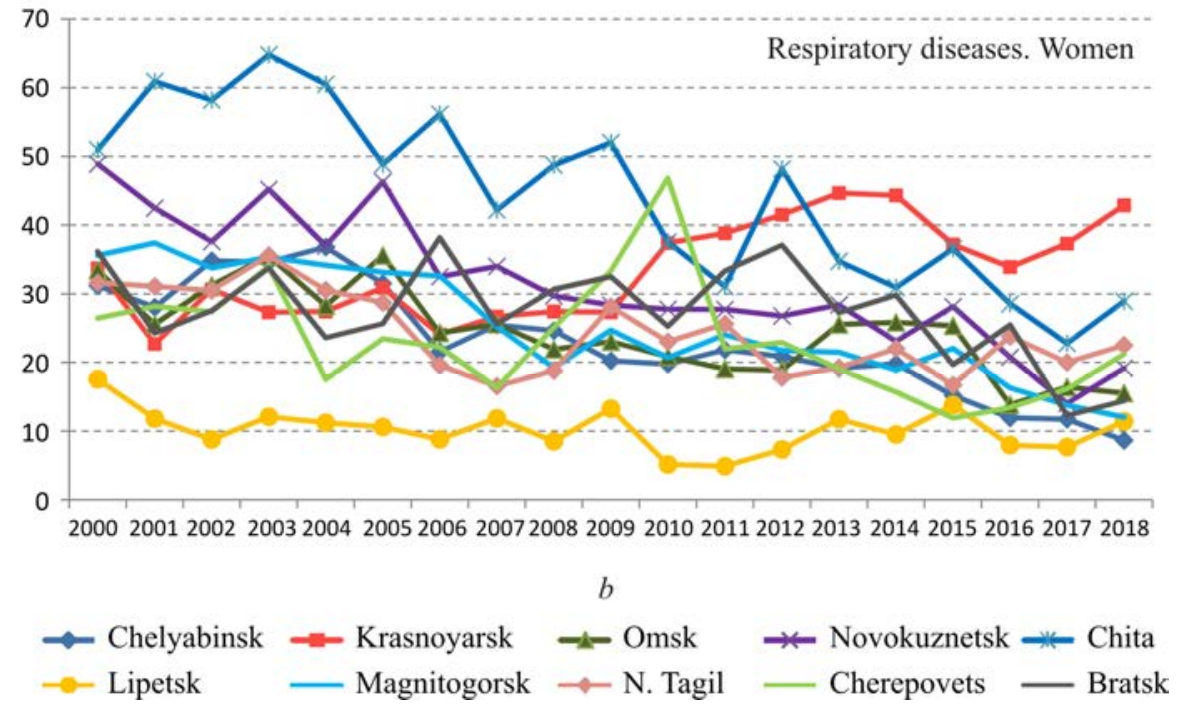

Figure 2 Standardized death rate from respiratory diseases in cities with different levels of air pollution, 2000-2018, per 100,000 of population ( $a-$ men, $b-$ women)

\footnotetext{
${ }^{2}$ On the state of sanitary and epidemiological well-being of the population in Krasnoyarsk Krai in 2017: State report. Krasnoyarsk, 2018, 301 p. (in Russian).
} 
Neoplasms. Estimating the impact of air pollution on cancer morbidity and mortality is a very difficult task, and it can only be solved using modern analytical epidemiological methods. However, this use may become a certain indicator for the cancer situation. The long-term average annual SDR from these diseases in most cities is very chaotic (Figure 3 ), but constantly higher than in the city of reference - Lipetsk, and asymptotic indicator $(p<0.001)$ shows the difference reliability.

It is known that, the main cause of men's death from malignant neoplasms is tracheal, bronchial and lung cancer. Despite the fact that the mortality level from this cause has some chaotic annual changes, we can still talk about the emerging trend of declining male mortality from his cause, while for women it remains relatively stable. At the same time, throughout the whole period, the mortality rate from tracheal, bronchial and lung cancer was higher in the cities, while in the reference city Lipetsk it was lower than the rates calculated for Russia as a whole. In some years, Novokuznetsk, Chita, Krasnoyarsk and Bratsk had the highest SDR rates of lung cancer for men.

Ecologically dependent changes in population health. After the second year of the Federal Project «Clean air», we were tasked to assess, using the standardized rate, such basic public health indicators, as mortality. In these most ecologically problematic cities, the mortality rate is much higher in all major disease groups, and there is not such a smooth decline in SDR than in such megacities as Moscow, St. Petersburg, Rostov-on-Don, which
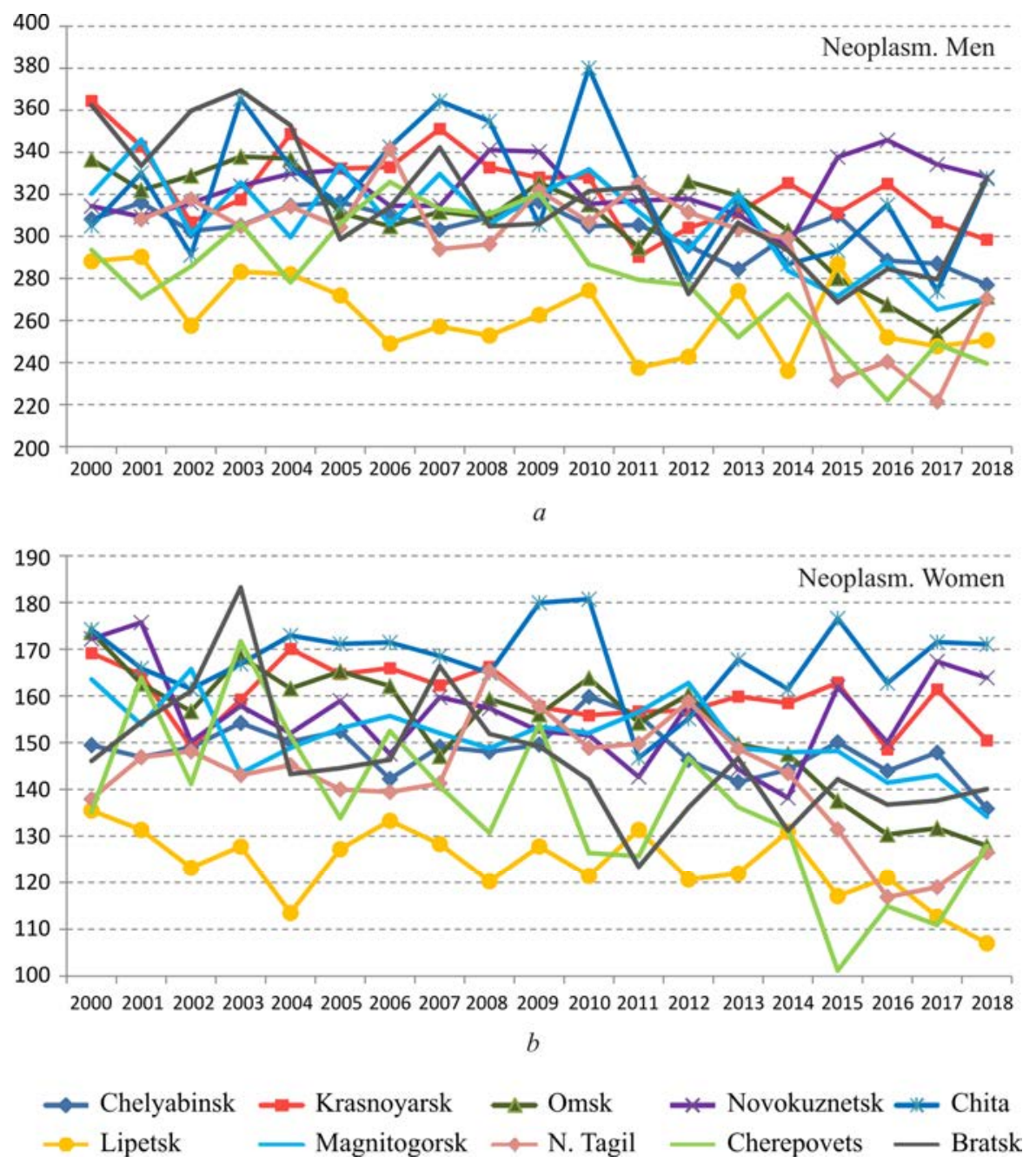

Figure 3. Standardized death rate from neoplasm in cities with different levels of air pollution, 2000-2018, per 100,000 of population ( $a$ - men, $b-$ women)) 
we conducted a similar analysis earlier for [6]. Comparing the structures of mortality by causes of death reveals both their similarities and differences: in the early 2000s, more than $70-80 \%$, and in 2018 , more than $60-70 \%$ of the causes of death of men and women are due to cardiovascular diseases (CVD), neoplasms and external causes. At the same time, the share of CVD everywhere takes the first place, although it is gradually decreasing, and women's share is more significant than men's. In the early 2000s, men's share is second in all cities except for Omsk and Lipetsk, for external causes, and neoplasms - taking third place. However, in the following years, as a result of a significant decrease in mortality from external causes, they moved to the third place, giving way to neoplasms, the proportion of which was almost twice as high as in external causes. Women had a slightly different picture: if in 2000, the external causes took ranked third place in the structure of mortality, in 2018, in most cities they moved to the fourth place, and in Omsk, Magnitogorsk, N. Tagil and Bratsk - even the fifth, ahead of respiratory and digestive diseases.

SDR, assessed by the median criterion, showed significant differences (less than 0.001) in comparison with the city of Lipetsk on cardiovascular diseases in men, neoplasms, respiratory diseases and cerebrovascular diseases. No differences significant at the level of 0.05 were found for other indicators.

Let's review the planned and partially implemented activities of «Clean air» project from the perspective of their effectiveness in improving the health of residents of the cities under consideration. The first results of the health risk assessment for emission reduction in Krasnoyarsk showed extremely low efficiency of the implemented emission reduction measures, the risk was reduced only for the group of 4.8 thousand people [7] that in a city with a population of 1.1 million may be useful only for 0.4 percent of residents.
The estimation of mortality data for cities with the most polluted air is consistent with previous studies on the health effects of carcinogens and other substances. Thus, in Norilsk, the population carcinogenic health risk is described as unacceptable. It is possible that it is the increased level of air pollution by carcinogens that has caused the high level of cancer incidence. Standardized incidence rates of lung cancer men were significantly higher compared to that of the region [8]. The authors of this study believe that such high rates as in Norilsk have no parallel in other regions of the country. Another epidemiological work published 5 years later, in 1992, reported a high incidence of lung cancer not only in men, but also in women [9], and a subsequent publication 10 years later reported a rising trend in cancer incidence, including young ages [10]. Carcinogenic risk assessment of atmospheric air is also given for Chita, where the population risk is characterized as elevated and makes 56.6 cases/year. The growth rate of cancer incidence is higher than in the country as a whole ${ }^{3}$.

Two cities in the Chelyabinsk region, included in the Federal project - Chelyabinsk and Magnitogorsk are constantly included in the list of cities with the highest level of air pollution with carcinogenic substances. This is due to the increased level of benz(a)pyrene in the air and the presence of other carcinogenic substances in metallurgical emissions [11]. Apparently, this is the reason for the higher standardised incidence of lung cancer and other population localizations in the left-bank part of the city where the smelter is located. In this part of the city similar indices were reliably $(p<0,05)$ exceeded for the right bank district: for men - lung cancer 1.7 times, stomach cancer - 1.5 times, skin cancer 2.3 times, for women - 1.2 times; 1.4 and 1.6 times respectively [12]. However, it should be noted that the author of this work does not specify whether the metallurgical plant em-

\footnotetext{
${ }^{3}$ Mikhailova L.A. Hygienic analysis of the urban environment impact on the oncologic morbidity of the population (on the example of the industrial centre of Siberia): author's abstract, Cand. of Medical Sciences. Irkutsk, $2009,139 \mathrm{p}$. (in Russian).
} 
ployees, including those who have professional contact with carcinogenic substances, have been excluded from the mortality analysis. In Chelyabinsk, the carcinogenic risk from exposure to contaminated air is also assessed as unacceptable in result of exposure to benzene, formaldehyde and chromium. The total carcinogenic population risk for 646,000 people made 297.4 additional cancer cases during 70 years of life [13]. There is an increase in carcinogenic risk indicators in comparison with previous years in the Orenburg region cities [14].

Use of health risk assessment methods, including carcinogenic risk, makes it possible to estimate hypothetical risks with a definite uncertainty degree, and it is very important for assessing the environmental situation in cities to identify the specific emissions sources of carcinogenic substances, in particular, develop measures to reduce them, improve methods for air pollution monitoring. However, from the point of the evidence-based medicine, techniques of analytical epidemiology are needed to prove carcinogenic effects. Anyway, they are very rarely used in the Russian studies to meet environmental and epidemiological challenges, and only two such works can be mentioned: on the assessment of workers exposure to lead at Moscow print shops in contact with lead-containing font [15] and on the assessment of dioxins impact on breast cancer incidence in women living near a chemical plant producing chlorinated pesticides [16].

A much higher number of publications are devoted to research on respiratory diseases, including those children. For the period from 2001 to 2011, according to official data, the total morbidity of children with bronchial asthma has increased from 971.2 to 1171.0 [17], as well as allergic diseases of the respiratory tract [18]. This applies not only to children, but also to adults in Krasnoyarsk ${ }^{4}$. Some Russian industrial cities (Novokuznetsk, Orenburg) have higher prevalence of respiratory diseases, including bronchial asthma in children, compared to other more environmentally friendly residential areas ${ }^{5,6}$. Almost all researchers reported higher prevalence of asthma-like symptoms and of bronchial asthma using an internationally standardized questionnaire. The survey results of 1,518 people aged 18-44 in Chelyabinsk city showed that the bronchial asthma prevalence is 3 times higher than official data [19].

As stated in the National program «Bronchial Asthma in Children. Treatment strategy and prevention», the current genetic studies have proven the role of hereditary predisposition to bronchial asthma development, but the endotype implementation is associated with environmental factors ${ }^{7}$. Indeed, fine particles present in the ambient air of any residential area, and especially of the industrial cities under consideration, are the risk factors for respiratory diseases development in children. For example, in Bratsk, the aluminium industry emissions and other sources of pollution have created such an unfavourable situation that respiratory diseases in children, including bronchial asthma, are registered more often than the regional average. A survey of children in the area affected by emissions from the aluminium smelter in Bratsk revealed an increased level of chronic respiratory diseases (2.9 times higher than in the comparison group), 5.5 times higher than functional disorders of autonomic and central nervous systems [20].

Results and discussion. For the first time in the recent decades, the Federal project «Clean air» has been developed, and substan-

\footnotetext{
${ }^{4}$ Gordeeva N.V. Structure of bronchial asthma incidence in Krasnoyarsk. Pharmacoepidemiology. Symptoms control: autoref. disk. Cand. of Medical Sciences. Krasnoyarsk, 2010, 120 p. (in Russian).

${ }^{5}$ Kurilova T.N. Clinical-epidemiological characteristics of bronchial asthma and allergy in schoolchildren of Novokuznetsk: author's abstract. Cand. of Medical Sciences. Novokuznetsk, 2003, 127 p. (in Russian).

${ }^{6}$ Skachkova M.A. Recidivating respiratory diseases in children in the industrial city: Cand. of Medical sciences. Orenburg, 2004, 270 p. (in Russian).

${ }^{7}$ Bronchial asthma in children. Treatment strategy and prevention: National program. $5^{\text {th }}$ Edition. Moscow, Originalmaket, 2017, 160 p. (in Russian).
} 
tial funding has been allocated for its implementation to improve air quality. However, both in selecting cities to be included in the project, and in determining the necessary actions, the results of many years of research into public health carried out by various scientific and educational organizations, including the Kemerovo, Krasnoyarsk, Omsk, Novokuznetsk, Novosibirsk and other medical universities and medical research institutes, were not used. The lack of proper professional interaction with physicians will be the reason why the formally stated goals of reducing the number of cities with high and very high levels of air pollution and increasing the share of citizens satisfied with the air quality in large industrial centers will not be achieved, and the financial cost of 500 billion rubles will not lead to the result expected. It should be noted that this amount also includes considerable costs to reduce air pollution from motor vehicles, but there is no substantiation for the proposed solutions, no developed models for optimizing transport flows, taking into account pollutant emissions and health risks assessment. In 2020, with COVID-19 pandemic, this epidemiological aspect of research became particularly crucial, given also some similarities between exposure to airborne fine particles smaller than 2.5 and $0.1 \mu \mathrm{m}$ and the COVID-19 virus. Fine particles absorb various toxic substances on their surface, penetrate bronchial tree and accumulate in lung tissues; smaller particles of less than $2.5 \mu \mathrm{m}$ in diameter $\left(\mathrm{PM}_{2.5}\right)$ reach bronchial tubes and alveole, and penetrate the bloodstream. Long-term exposure to high concentrations of these particles increases mortality from respiratory and cardiovascular diseases (myocardial infarction, stroke, coronary heart disease and other diseases).

In early April 2020, Harvard School of Public Health published the results of the pilot study to estimate mortality from this disease in the United States localities, where $90 \%$ of the population of this country lives, showing the correlation between an increase in mortality from COVID-19 and concentration of RM2.5 in ambient air, i.e. with an increase in the concentration of these particles by $1 \mu / \mathrm{m}^{3}$ there is a $15 \%$ increase in mortality. The mathematical model here took into account the population density, the number of hospital beds, socioeconomic, behavioral and other factors [21].

Health assessment in 12 cities of the Federal project is carried out by Rospotrebnadzor scientific institutes based on the use of risk assessment methodology. Such studies are usually conducted to identify the priority pollutants with the highest risks to public health, to justify the necessary measures to reduce emissions of specific toxicants, as well as the size of sanitary protection zones and other environmental issues. However, the indicators for urban population health associated with air pollution are not only the modeling estimates, but also the natural indices mortality, morbidity, prevalence, including children's bronchial asthma, presence of malignant neoplasm locuses, results of studies on children's health, reproductive health, data from various registers, including congenital malformations. For 12 cities of the Federal project, it is necessary to analyze the prevalence of asthma-like symptoms and bronchial asthma among children using the international standardized questionnaire ISAAC. The results of this study for 17 regional centers, including Novokuznetsk and the Chelyabinsk region, allowed to determine the prevalence of the verified diagnosis of bronchial asthma based on meta-analysis, and compare it with European indices [22]. Application of this method makes it possible to trace the dynamics of the disease prevalence and evaluate the effectiveness of activities to improve ambient air quality, as well as preventive measures by the public health authorities. The pilot project in this direction can be carried out in Krasnoyarsk, especially considering the experience of the Department of Pediatrics of the Krasnoyarsk State Medical Institute named after Prof. V.F. Voyno-Yasenetsky ${ }^{8}$. In this

\footnotetext{
${ }^{8}$ Stepanova L.V. Clinical and organizational problems of bronchial asthma in children of Krasnoyarsk and their solution: Author's abstract. Candidate of Medical sciences. Krasnoyarsk, 2009, 207 p. (in Russian).
} 
city, as well as in Bratsk and Novokuznetsk, oncoepidemiological studies are needed, given the high carcinogenic risk of exposure to contaminated air. The presence of this risk may justify the additional funding for early cancer diagnostics, oncological prevention and evidence-based oncoepidemiological studies. We believe that in Siberian cities radical changes in air quality and improvement of public health are possible only after reduction of coal use or modernization of power plants with reduction of particulate emissions.

To better assess the impact of various environmental and lifestyle factors on the health of urban populations in New York, London, Berlin, Singapore and other capitals, other indicators and for this purpose, scientific organizations or health authorities have established special units [23]. Urban health has become a subject of discussion in our country, for example, at annual international Urbanist forums in Moscow.

An effective environmental policy to reduce the emission of suspended particles has resulted in not only a reduction in the concentrations of these particles in the air of cities in Europe, the United States and other countries of the Organization for Economic Development and Cooperation, but also to a reduction in additional mortality rates. As a consequence, life expectancy at birth in the USA increased by $0.61 /$ year from 1980 to 1990 (this calculation naturally also took into account the impact of socio-economic factors) [24]. Thus, the benefits of reducing ambient air pollution could lead to the achievement of both national demographic and health project objectives, provided adequate interaction with these projects and medical community.

Funding. The research was carried out within the framework of the state task of IEF RAS «Formation and adjustment of the short-, medium- and long-term forecasts for the development of the social sector of economy».

Conflict of interests. The authors state that there is no any conflict of interest.

\section{References}

1. Revich B.A. Effektiven li proekt «Chistyi vozdukh» dlya uluchsheniya zdorov'ya naseleniya 12 gorodov? [Is «Clean air» project effective in improving the health of population in 12 cities?]. Ekologicheskii vestnik Rossii, 2020, no. 3, pp. 58-68 (in Russian).

2. Kislitsin V.A., Novikov S.M., Shashina T.A., Skvortsova N.S., Savelyev S.I., Kandybin V.P., Samsikov Ye. A. Use of health risk estimates for substantiating the boundaries of sanitary protection zones of the Novolipetsk metallurgic works. Gigiena i sanitariya, 2006, no. 5, pp. 98-100 (in Russian).

3. Savelyev S.I., Bondarev V.A., Nakhichevanskaja N.V., Polyakova M.F., Yuriev G.A., Saltykov V.M., Golovanova E.A. Using data from a regional information fund of social and environmental health monitoring to assess human health risks in Lipetsk. Health Risk Analysis, 2013, no. 1 , pp. 41-51. DOI: $10.21668 /$ health.risk/2013.1.06.eng

4. Arutyunyan R.V., Vorob'eva L.M., Panchenko S.V., Pechkurova K.A., Novikov S.M., Shashina T.A., Dodina N.S., Goryaev D.V. [et al.]. Environmental safety assessment of Krasnoyarsk Krai based on a public health risk analysis. Atomnaya energiya, 2015, vol. 118, no. 2, pp. 113-118 (in Russian).

5. Dolgushina N.A., Kuvshinova I.A. Air pollution and non-cancenogenic risk assessment in industrial cities of Chelyabinsk region. Ekologiya cheloveka, 2019, no. 6, pp. 17-22 (in Russian).

6. Revich B.A., Khar'kova T.L., Kvasha E.A. Prodolzhitel'nost' zhizni i smertnost' v megapolisakh [Life expectancy and mortality in megacities]. Chelovek v megapolise: opyt mezhdistsiplinarnogo issledovaniya. In: B.A. Revich, O.V. Kuznetsova eds. Moscow, LENAND Publ., 640 p. (in Russian).

7. Popova A.Yu., Zaitseva N.V., May I.V. Population health as a target function and criterion for assessing efficiency of activities performed within «Pure air» federal project. Health Risk Analysis, 2019, no. 4, pp. 4-13. DOI: 10.21668/health.risk/2019.4.01.eng 
8. Pisareva L.F., Peshkova E.A., Goryachev S.M., Dettsel' A.E. Osobennosti onkologicheskoi zabolevaemosti v Zapolyar'e [Peculiarities of cancer morbidity in the Polar Region]. Epidemiologiya, profilaktika $i$ rannyaya diagnostika zlokachestvennykh novoobrazovanii. Tomsk, 1987, pp. 73-75 (in Russian).

9. Karasev V.V., Dettsel'A.E., Shtarik V.A., Dykhno Yu.A. Zabolevaemost' naseleniya Noril'skogo promyshlennogo raiona rakom legkogo [Incidence of lung cancer in the population of Norilsk industrial district]. Voprosy onkologii, 1992, no. 38 (11), pp. 1340-1344 (in Russian).

10. Ananina O.A., Pisareva V.F., Odintsova I.N., Khristenko E.L., Popkova G.A., Khristenko I.D. Cancer incidence among population of Norilsk. Formation of high risk groups for cancer. Sibirskii onkologicheskii zhurnal, 2013, no. 4, pp. 58-61 (in Russian).

11. Antipanova A.N., Koshkina V.S. Sotsial'nyi «ushcherb» kantserogennogo riska zdorov'yu naseleniya krupnogo tsentra chernoi metallurgii $\mathrm{v}$ sisteme sotsial'no-gigienicheskogo monitoring [Social «damage» of carcinogenic risk to health of population in a large ferrous metallurgy center in the system of social and hygienic monitoring]. Izvestiya Chelyabinskogo nauchnogo tsentra, 2007, no. 2 (36), pp. 101-105 (in Russian).

12. Koshkina V.S., Antipova N.A., Kotlyar N.N. Monitoring rasprostranennosti khimicheskikh kantserogenov v ob"ektakh okruzhayushchei sredy i biosredakh u zhitelei goroda s razvitoi otrasl'yu chernoi metallurgii [Monitoring of the spread of chemical carcinogens in the environmental objects and biospheres in dwellers of a town with a developed sector of ferrous metallurgy]. Gigiena $i$ sanitariya, 2006, no. 1, pp. 12-14 (in Russian).

13. Valeulina N.N., Efremova V.M., Beketov A.L., Brylina N.A., Nikiforova E.V., Grechko G.Sh., Kolotova T.S. Otsenka riska dlya zdorov'ya naseleniya ot vozdeistviya khimicheskikh veshchestv, opredelyaemykh v atmosfernom vozdukhe goroda Chelyabinska za 2015-2017 gg. [Assessment of public health risk from exposure to chemicals defined in the atmospheric air of Chelyabinsk city for the period 2015-2017]. Aktual'nye voprosy analiza pri obespechenii sanitarno-epidemiologicheskogo blagopoluchiya naseleniya i zashchity prav potrebitelei: materialy IX Vserossiiskoi nauchno-prakticheskoi konferentsii, 2019, pp. 95-100 (in Russian).

14. Boev V.M., Kryazhev D.A., Tulina L.M., Neplokhov A.A. Assessment of carcinogenic health risk for population living in monocities and rural settelements. Health Risk Analysis, 2017, no. 2, pp. 57-64. DOI: 10.21668 /health.risk/2017.2.06.eng

15. Il'icheva S.A., Zaridze D.G. Evaluation of the carcinogenic risk of lead in the cohort study of male workers occupationally exposed to inorganic lead in 27 Moscow printing-houses. Gigiena $i$ sanitariya, 2015, vol. 94, no. 5, pp. 75-80 (in Russian).

16. Revich B.A., Ushakova T.I., Sergeev O.V., Zeilert V.Yu. Breast cancer in Chapayevsk. Gigiena i sanitariya, 2005, no. 1, pp. 18-21 (in Russian).

17. Balabolkin I.I., Terletskaya R.N., Modestov A.A. Allergic child morbidity in actual ecological conditions. Sibirskoe meditsinskoe obozrenie, 2015, no. 1 (91), pp. 63-67 (in Russian).

18. Il'ina N.I., Luss L.V., Nazarova E.V. Environment and Allergies. Meditsinskii opponent, 2019, no. 2 (6), pp. 12-17 (in Russian).

19. Zakharova N.A. prevalence of bronchial asthma in young people living in industrial city. Kazanskii meditsinskii zhurnal, 2014, no. 95 (4), pp. 548-552 (in Russian).

20. Zaitseva N.V., Zemlyanova M.A., Kol'dibekova Yu.V., Zhdanova-Zaplesvichko I.G., Perezhogin A.N., Kleyn S.V. Evaluation of the aerogenic impact of priority chemical factors on the health of the child population in the zone of the exposure of aluminum enterprises. Gigiena $i$ sanitariya, 2019, vol. 98, no. 1, pp. 69-75 (in Russian).

21. Wu X., Nethery R.C., Sabath B.M., Braun D., Dominici F. Exposure to air pollution and COVID-19 mortality in the United States: A nationwide cross-sectional study. MedRxiv, 2020, no. 7, 20 p. DOI: $10.1101 / 2020.04 .05 .20054502$

22. Batozhargalova B.Ts., Mizernitskii Yu.L., Podol'naya M.A. Meta-analysis of the prevalence of asthma-like symptoms and asthma in Russia (according to the results of ISAAC). Rossiiskii vestnik perinatologii i pediatrii, 2016, no. 4, pp. 60-69 (in Russian). 
23. Ganzhinova S., Krasnoperova I., Mal'tsev G., Rachev P., Rumyantsev N. Urban Health. Moscow, Analiticheskii tsentr «Moskovskii urbanisticheskii forum» Publ., 2019, 600 p. (in Russian).

24. Pope A., Ezzati M., Dockery D.W. Fine-particulate air pollution and life expectancy in the United States. N. Engl. J. Med, 2009, vol. 360, no. 4, pp. 376-386. DOI: 10.1056/NEJMsa0805646

Revich B.A., Khar'kova T.L., Kvasha E.A. Selected health parameters of people living in cities included into "Clean air» federal project. Health Risk Analysis, 2020, no. 2, pp. 16-27. DOI: 10.21668/health.risk/2020.2.02.eng

Received: 09.06.2020

Accepted: 23.06.2020

Published: 30.06.2020 